\title{
The Strategic Use of Liberal Internationalism: Libya and the UN Sanctions, 1992-2003
}

\author{
Ian Hurd
}

\begin{abstract}
The UN's sanctions against Libya became an issue of great controversy in the Security Council in the 1990s owing to competing interpretations of the central legal norms of international relations. The norms of due process, the presumption of innocence, and respect for international organizations (IOs) were defended by both sides, but for opposite ends. I use the contestation over norms and law at the Council to argue three broader themes about international politics: first, that states' perceptions about the legitimacy of international institutions is important in influencing state behavior; second, that this legitimacy creates powerful symbols in international relations that are strategically useful to states in the pursuit of their interests; and third, that the distribution of material power among states does not necessarily parallel the distribution of symbolic power, and so it is not uncommon for apparently strong states to be defeated by apparently weak ones when they fight over symbolic stakes. The norms of liberal internationalism are intersubjective resources useful in the strategic competition among states.
\end{abstract}

When Libya was faced with United Nations (UN) sanctions in the early 1990s, it was a relatively weak state in a confrontation with a relatively unified international community. Lacking coercive resources or powerful allies, the Libyan strategy to undermine the sanctions rested on appropriating the symbols and norms of liberal internationalism and deploying them in a counterattack. Because the proponents of the sanctions had based their case in the Security Council on the norms of due process, respect for international organizations (IOs), and peaceful dispute settlement, international support for the sanctions was sensitive to new interpretations of these principles. Libya's strategy took advantage of this fact and, by consistently pressing a reinterpretation of liberal internationalism and of the norms of the Council, it was able to delegitimize the sanctions and threaten the legitimacy

For helpful comments on earlier drafts, I wish to thank the editors and anonymous reviewers of this journal, as well as Jose Alvarez, Stephen Brooks, Michael Doyle, Daryl Press, Henry Shue, Benjamin Valentino, Jennifer Welsh, William Wohlforth, and seminar participants at Columbia Law School, Dartmouth College, Oxford University, and ISA Montreal 2004.

International Organization 59, Summer 2005, pp. 495-526

(C) 2005 by The IO Foundation.

DOI: $10.1017 / \mathrm{S} 0020818305050186$ 
of the Council itself. Quite surprisingly for an Arab nationalist dictatorship, Libya publicly championed liberal internationalism and sought to reinforce the legitimacy of international law and organizations. Libya's tactic created a dilemma for the prosanctions states: continuing to insist on the sanctions regime in the face of rising defections by UN members increased the risk to the credibility of the Council. ${ }^{1}$ Faced with a trade-off between defending sanctions and defending the Council itself, the United States and United Kingdom (UK) eventually agreed to a compromise in 1998 that they had earlier rejected. Their interest in preserving the power of the Council won out over their desire to maintain a hard line against Libya.

The history of the Libyan sanctions case reveals a number of themes of interest to international relations (IR) theorists. In the specific crisis between the two coalitions, it demonstrates that power politics is far from limited to military confrontations. Militarily weak states such as Libya can use resources that are endogenous to international society as levers against militarily powerful states. More generally, it shows how international politics is often carried out using tools derived from or controlled by international institutions, and that perceptions of legitimacy are crucial to these institutions. However, this structure is at the same time vulnerable to reinterpretation and contestation. This is instructive at a time when the nature of U.S. foreign policy and its relationship to international institutions is under debate. Finally, it illustrates empirically a complementary relationship between norms and strategic interests that many others have begun to chart conceptually.

This article examines the arguments used by the two sides to convince thirdparty states to either support or oppose the sanctions regime. ${ }^{2}$ The debates over the original sanctions resolutions set the terms of the debate and anchored it in the norms of liberal internationalism. The first two sections of the article set out the concepts and methods used in the empirical analysis and chart the operation of legitimation and delegitimation in power politics. Then, the bulk of the article charts the debates over the resolutions and then the subsequent back-and-forth between the parties as they reacted to each other's arguments and maneuvering. I highlight the contestation over the appropriate interpretation of norms of due process, procedural justice, and the nonuse of force. The final substantive section argues that the compromise of 1998 was generated out of this contestation and that it was the fear of delegitimation of the Council that motivated the United States and the UK to accept it. Comparing my explanation to two competing accounts of the compromise helps to both situate the argument relative to others and to show its limits. In conclusion, I point to three generalizations that one can draw from the case (about legitimacy, contestation, and material power) that can motivate research in other empirical cases.

1. Drezner identified in theory the possibility of this kind of dilemma in Drezner 2000.

2. The UN sanctions regime began in 1992 and did not formally end until 2003, although the sanctions were suspended in 1999. 


\section{Concepts and Methods}

This article's approach cuts across several intellectual currents and takes positions in a variety of methodological controversies. These controversies are worth making clear up front. Although this is not primarily an article about methodology or epistemology in IR, the nature of the empirical problem under research here made it necessary to draw from different approaches in novel ways. This may be of interest to others analyzing interesting but unconventional puzzles in the international system. A few words, therefore, are warranted to situate my approach relative to three ongoing controversies in IR. The three relate to, first, the relationship between norms and strategic choice; second, the nature of the power of IOs; and third, the significance of legitimacy to the international system.

This article explores states' use of international norms and institutions in the pursuit of strategic interests. As such, it straddles the realms of strategic choice and of norms, two worlds that are traditionally kept separate in IR theory. By positing from the start that states are strategic actors embedded in a socially constructed environment, the article suggests that constructivism and rational choice are essential complements to each other in IR rather than antagonists, as is sometimes supposed. Several important recent papers have developed the conceptual foundations for such a position, ${ }^{3}$ and what follows here is an empirical case that demonstrates the payoff that comes from joining the two. The outcome of the case is similar to what Schimmelfennig finds with respect to European Union (EU) and North Atlantic Treaty Organization (NATO) enlargement: it is "the result of social construction on the basis of intersubjective ideas but the construction was done by strategic actors using these ideas instrumentally for their selfish purposes." 4

Second, this article enters into the debate over the power of IOs. The typical framing of debates in academic IR about the nature of IOs is to look for evidence of their power in one of two ways: either (1) by asking, "Do states comply with the decisions of IOs when it is costly to do so, and if so, why?" or (2) by asking, "do IOs shape the interests of states, and if so, how?" ${ }^{5}$ One can conclude that IOs are powerful if the answer to either of these questions is yes. My approach is different. Reflecting an ontological starting point in which states are modeled as

3. For instance, Fearon and Wendt 2002; Barnett and Duvall 2005; and Finnemore and Sikkink 1998.

4. Schimmelfennig 2003, 283.

5. On the first question, compare, for instance, Mearsheimer 1994/95 ("[institutions] have no independent effect on state behavior," p. 7) to his institutionalist critics such as Keohane and Martin 1995 ("institutions operating on the basis of reciprocity" are unavoidable in "any lasting peace," p. 50), and Chayes and Chayes 1995 ("[states] do not negotiate agreements with the idea that they can break them whenever the commitment becomes 'inconvenient,"' p. 7). On the second question, see Finnemore's account of changing interests as compared to Gruber's story of institutions imposed by the strong on the weak. Finnemore 1993; and Gruber 2000. In Barnett and Duvall's typology of power for IR, the first question involves a debate over whether "institutional" power exists at all in the international system, while the second question is about whether institutional power can be "constitutive" of actors or merely "interactional." Barnett and Duvall 2005. 
strategic actors in socially constructed contexts, I see the power of IOs as contributing to shaping the context of action for states. ${ }^{6}$ This effect might come about if the IO generates new kinds of resources that states find useful, or if the organization shapes their interests through socialization. This article looks only at the former, but in either case the existence of the organization affects the structure of payoffs faced by the state as it contemplates its options. For instance, in the U.S.Iraq crisis of 2002-03, American decision makers believed that winning the support of the UN Security Council for regime change in Iraq would increase their power relative to Iraq and to third-party countries. Conversely, these decision makers also knew that failing to gain the support of the Council would increase the costs of a U.S. attack. In both directions then, the existence of the Council affected the strategic environment in which the Bush administration had to make its decisions. ${ }^{7}$ The potential to reduce the costs of war was the incentive that encouraged the United States to invest in the effort to win Council approval in $2003 .{ }^{8}$

Finally, this approach to power focuses on the importance of legitimation to international institutions. Being seen as legitimate makes an institution an attractive resource for states. For states that see an institution as legitimate, it contributes to the process of socialization that can shape their perceptions of their interests. For those states that do not find an institution legitimate, it provides a means to manipulate those that do. A legitimized institution can delegate some of its power to others through the medium of symbols. The symbols of an institution can be used by others in ways that further their interests. ${ }^{9}$ In the UN's case, this might mean peacekeepers' blue helmets or the Council's imprimatur on a resolution. International institutions lack instruments of direct coercion, and so the control that they have over access to their symbols may be one of few levers in their control to influence the behavior of states. IOs have power over states to the extent that states are willing to "pay" for the use of the IOs symbols, and the symbols are valued to the extent that the organization itself is seen as legitimate in the international community. This can be seen in the rhetorical power that comes from being associated with both informal institutions (such as the rules and procedures of international law) and formal organizations (such as the UN Security Council).

At the broadest level, this research is a study of how power politics works in interstate disputes. The resources that states bring to bear in this case are intersubjective- they have value as tools of power relative to other states only because actors believe them to be powerful — but the model of states themselves is very much that of traditional IR: instrumental, self-regarding, strategic actors.

6. See Johnston 2001, whose emphasis is on cooperation rather than contestation.

7. In the long run, states can make or remake international institutions, but in the crucible of a crisis they generally must accept them as they currently exist. This is true even for strong states.

8. Hurd 2005.

9. On symbols in international politics, see O’Neill 1999; and Hurd 2002. 
I do not examine the original construction of the resources the actors use. ${ }^{10}$ This is not in question here because the states involved in the dispute simply made use of what tools were already available to them. I also do not probe the outer limits of intersubjective power to see how far interpretations can be stretched before they are rejected by the audience. ${ }^{11}$ I also do not presume that arguments need necessarily be related to the "truth" to be powerful. There are many interesting ways in which validity claims make arguments more powerful, ${ }^{12}$ but the Libyan case shows also how even (presumably) cynical uses of international norms can affect the outcome of interstate disputes.

In the literature on economic sanctions, it is conventional to focus on the incentives faced by potential enforcing states to comply or defect with the regime. These decisions are complex, and states must consider a variety of costs and benefits, including foregone trade, reputation costs, the likelihood of success, and the value of the underlying principle the sanctions are intended to defend. Multilateral sanctions are even more complex than unilateral sanctions because they introduce the challenges of managing cheating, free riding, and incomplete information about others' intentions. Such situations lend themselves well to multivariate analysis of expected utility and to game-theoretic models of states' options. ${ }^{13}$ But these approaches should not lead one to neglect the important socially constructed nature of the decision situation. In the case discussed below, the instruments with which Libya pursued its strategic interests, and the goods that they sought in the compromise, were in part intersubjective in nature. Status and prestige, for instance, are valuable to states because they are constructed out of a shared understanding of a normative hierarchy. Understanding the strategic nature of Libya's response requires attention to the social, intersubjective facts of symbols and institutions that constitute the resources available to rational actors and the terrain on which their political interactions are played. The origins and functioning of these resources are not part of the rationalist paradigm, even though their use in the pursuit of strategic interests is certainly compatible with it. Moving outside the rationalist approach does not mean that one begins by assuming that states are acting irrationally. Some authors who focus on "rogue states" are

10. Crawford provides a model of how these resources might be created out of culture, beliefs, and identity; see Crawford 2002. Where Crawford looks at how new agreement on old controversies (such as the ethics of colonialism) might be achieved through argument, Mattern studies the disassociative effect of crisis and argument. Mattern examines how interstate disputes can undermine existing understandings of identity and community and yet simultaneously the representational force of language/ power can reconstitute them. Mattern 2004.

11. Johnstone nicely situates the Security Council within an "interpretive community" that judges the plausibility of rhetorical claims made there; see Johnstone 2003. This draws on Habermas's interest in the constraints that exist on communicative action because of the public commitments that underlie intersubjective meaning in the first place. See also Heath 2003, 23-24.

12. Also indebted to Habermas, Risse identifies a mode of international politicking ("argumentative rationality") where power accrues to actors who attach their positions to accepted understandings of what is true; see Risse 2000. Also see Lynch 2002.

13. See Martin 1992; and Drezner 2000. 
in danger of falling into this trap. Doxey's useful review of sanctions episodes begins its treatment of the Libyan case by noting that "Libya is a maverick state" and infers from that that little can be predicted or understood about Libyan President Muammar Qaddafi's motives or behavior. ${ }^{14} \mathrm{~A}$ more productive approach comes from exploring the construction of the decision situation in which actors find themselves.

These are the conceptual foundations on which the empirical research of this article is based. Although there is much controversy over each of these three positions, and a full defense of them is beyond the scope of this article, it is useful to be explicit about them. This is for two reasons. First, disagreements over the interpretation of the Libyan sanctions case can, in part, be traced back to disagreements embedded in these more conceptual debates. Second, the empirical case helps shed light back onto these controversies. Thus, the payoff of the case is in part that it shows empirically the value of making these methodological choices.

\section{Legitimacy, Power, and Contestation}

Strong actors prefer to exercise social control through the use of legitimate institutions than through direct coercion because it generally carries lower social costs. ${ }^{15}$ When actors believe that a rule or institution is legitimate, they have an internal bias in favor of compliance. ${ }^{16}$ Hegemons that can instill this belief regarding institutions that they favor are thereby able to perpetuate their advantage more efficiently than they could through direct force. ${ }^{17}$ The symbols associated with a legitimized institution can be appropriated by other actors and used as resources of power in their own right. Sometimes these take the form of public goods, available to all, and sometimes they are controlled by gatekeepers. Norms are classic examples of the public-goods type of symbols: any player can make a rhetorical defense of its actions in the language of liberal internationalism, for instance. The only check on the misuse of these norms comes from the limits of what the audience is willing to accept as meaningful. ${ }^{18}$ On the other hand, the symbols of UN peacekeeping (blue helmets, neutrality, and Council approval) are an example of symbols managed by a gatekeeper: they can only be used by agents who have the

14. Doxey 1996, 45.

15. Hurd 1999. The costs of becoming "entrapped" are considered below.

16. My approach relies on a subjective definition of legitimacy: an institution is legitimate for an actor only when the actor believes it to be. This is appropriate given my interest in observing the behavioral implications of legitimation in IR. An objectivist conception of legitimacy, as used for instance by Buchanan, relies on an external standard to assess whether the actor's belief in legitimacy is wellfounded or not. See Buchanan 2003. It is ironic that the objectivist approach is necessary to get at normative questions about the ethics of institutions, while the subjective approach is more useful for "scientific" explanations of behavior.

17. Ikenberry and Kupchan 1990.

18. Heath 2003. See, for instance, Johnstone 2003 on "interpretive communities." 
approval of the Security Council, and the Council can impose conditions on (extract "payment" for) the use of its symbols. ${ }^{19}$

Although legitimated rule is cheaper to enforce than is coercion, it carries dangers as well. Legitimacy is lost if the hegemon is too often interpreted as itself violating the rules of the game. Because "hypocrisy" is dangerous to legitimation, hegemons can find themselves entrapped by their own institutions and pressured to act in ways that they would rather not. ${ }^{20}$ This might come about in obvious ways, as when the United States failed to convince the Council in 2003 to approve the Iraq invasion and then paid a premium for going ahead unilaterally, or in subtle ways, as when aid agencies let the norm of rescuing women and children first trump their stated objective of saving those in greatest danger. ${ }^{21}$ In addition, legitimated power generates forms of opposition that are different than those that arise in reaction to coercion. When the power of a legitimated institution is used to achieve favored outcomes, the results are vulnerable to competing players who present a different interpretation of the institution, one that either points to a different legitimate outcome or one that delegitimizes the institution altogether. The need to reproduce the legitimacy of the institution over time opens the possibility of "competitive reinterpretations" of its meaning. The social and intersubjective nature of legitimacy means that it is at once a source of great structural power for institutions but also uniquely fragile. Reinterpretation is not really an option when faced with physical coercion, but it can be a powerful strategy for undermining the power of legitimated institutions. ${ }^{22}$

The contestation over, and ambiguity of, norms is an important aspect of world politics that is often overlooked in IR, even among constructivists. Constructivists and others in IR have often struggled to establish that the fact that while international structures such as balances of power and arms races are socially constructed, this does not mean that they cease to exist as soon as one actor "changes its mind" about their meaning. But in working to make that case, constructivists have often overstated the consensus that exists over norms. Claude, who was certainly a constructivist in this context, made a convincing case in an important article in 1966 that the strength of the UN lies in large measure not in the application of material power in order to change states' behavior, but in the ability to confer or withhold the legitimation of the international community on states and their acts. ${ }^{23}$ Claude pointed to the political power of statements by organs of the UN, and recognized that the source of that power is the grant of legitimacy that is involved when states behave as if these statements are important enough to fight over. However, Claude's image of legitimacy and authority was something of a

19. Hurd 2002.

20. See Risse 2000 on "self-entrapment."

21. On the latter, see Carpenter 2003.

22. This incompleteness inherent in the authority of all social institutions leads Connolly to declare the "ambiguity of authority" as a general condition. See Connolly 1987, 20-21.

23. Claude 1967. 
one-way street, running parallel to the international legal process, along which states might cede legitimate authority to an interstate organization, which then "stores" it to dispense when called on. Similarly, explanations for the spread of norms based in "epistemic communities" frequently take this approach. For instance, Finnemore's study of the role of the UN Educational, Scientific and Cultural Organization (UNESCO) in the spread of national science policies among states sees the IO as norm-suppliers and states as buyers, consumers, or learners. ${ }^{24}$ Competition and uncertainty over the meaning of norms, along with the politics that this engenders, is left for others to explain.

The uniform image of centralized, legitimacy-supplying authority exaggerates the coherence of legitimation. The construction of a legitimate institution is never complete in the sense that all relevant actors accept the construction, or accept it in the same way, or that it is self-perpetuating. It is always "under construction." The incompleteness expresses itself in many ways. For one, communities are never unanimous in their assessment of the legitimacy of institutions and, therefore, never entirely settled on their interpretations of the content of the institutions' symbols. There are always dissenting opinions within a society, inevitably accompanied by struggles and contests to declare the legitimacy of one set of interpretations and not another. The struggles over authority are perhaps the most interesting aspects of social affairs and are often attended by great tragedy and violence. In the case of such instability, institutions must be constantly reinforced by the supportive behavior and statements of actors. Absent this reinforcement, institutions will collapse. Where different interpretations of legitimacy are held by different actors, the strength of the institution comes from the degree of overlap among them. A relatively solid institution is merely one where interpretations coincide to a greater degree. There may also be inconsistencies within an actor itself, in that an actor might have attachments to several institutions or norms simultaneously that could require divergent or even opposite reactions to a situation. These inconsistencies can last for extended periods and culminate in a crisis only when the actor faces a situation that calls on both internalized beliefs at the same time. ${ }^{25}$

Opponents of the status quo can use the natural incompleteness of authority to undermine the existing power relations in the system. Much of the "normal politics" in domestic legal and political life involve efforts to exploit this ambiguity inherent in the service of parochial interests, both by the weak and by the strong. This is obviously possible for the strong, but it is particularly interesting in the case of the weak. Sociologists and anthropologists report that resistance works best when presented in terms borrowed from the language of the authority, and where the point is not to challenge the existing authority head-on but to argue that

24. Finnemore 1993; see Barnett and Finnemore 1999. Also, Levy's article on policy learning is notable for putting the learner's cognitive filters and theories ahead of the unmediated transfer of norms. See Levy 1994.

25. See Mattern 2004, chap. 3, for a good discussion of this. 
the existing authority is not being true to its professed values. For instance, Epstein has shown how the popular radicals in England in the late eighteenth and early nineteenth centuries relied on the established traditions of English constitutionalism to make their case for reform or revolution. The rhetoric of the new and competing idiom of Thomas Paine and the American and French Revolutions was present, but secondary to "the borrowed language of the past." ${ }^{26}$ In similar terms, the Puritans of the English Revolution first declared their grievances in a Petition of Right, recalling the Magna Carta. ${ }^{27}$ Scott sees this as a general pattern, suggesting that most social revolutions begin as demands that the existing authority simply better honor its commitments. ${ }^{28}$ These cases support the common observation that material weakness does not necessarily mean powerlessness. The weak might find power by reinterpreting the values of hegemonic actors in ways that the hegemon cannot simply dismiss.

The UN Security Council is an excellent location to observe such mobilizations in international politics. The dominant states are more secure in their dominance to the extent that the Council is accepted as legitimate, and as a result they are concerned with maintaining the Council's legitimacy. If legitimacy is a source of power for the Council and for its most powerful members, then they have an interest in responding to threats to that legitimacy. In the earliest debates on the founding of the UN, the dominant states had to reconcile the interest in egalitarianism and democracy with the desire for veto control over the Council. They legitimized the inequalities of the Council by granting informal assurances about their limited intentions for the veto, and about their commitments to democratic procedures in the Council. These promises increased the costs for the future of promiscuous use of permanent members' privileges. In the case of the Libyan sanctions, a weak state pursued a strategy of calling back into question these commitments of the great powers and used the rhetoric of the United States and the UK to undermine their preferred policy.

\section{UN Sanctions Against Libya}

The Lockerbie episode entered the Security Council's agenda on 30 December 1988 with a statement by the Council President condemning the bombing of Pan Am Flight 103 (which had crashed in Lockerbie, Scotland, nine days earlier). By 1990, Western intelligence identified two Libyan agents as centrally involved in planting the bomb, and the United States and the UK began a campaign to hold a legal trial of the two and perhaps others. To pressure Libya to cooperate, the UN Security Council issued two resolutions imposing sanctions against Libya, the first

26. Epstein 1994, 4. Also see Hearn 1975.

27. Hendel 1958, 12.

28. Scott 1990 . 
(Resolution 748) in March 1992 and the second (Resolution 883) in November 1993. An earlier resolution, 731, provided the backdrop to these decisions in that it defined the changes in policy that were required of Libya. When Libya ignored this first resolution, it provided the rationale for the sanctions. Resolution 731 noted four demands, which were first spelled out in two statements of the United States, UK, and France in November 1991 and later pressed with the enforcing Resolutions 748 and 883 . These demands were that the government of Libya surrender for trial all those charged with the bombing crimes and accept complete responsibility for the actions of Libyan officials; that the government disclose all it knew about the crimes, including the names of those responsible and allow access to witnesses, documents, and other material evidence; that it pay appropriate compensation to the victims' families; and that it commit itself to cease all forms of terrorist action and support to terrorist groups. The first three demands were contained in a joint U.S.-UK statement, and the fourth in a United States-UK-France statement. ${ }^{29}$ The three resolutions of the Council did not spell out these demands but rather made reference to the two statements and then expressed, in Resolution 731, that it "strongly deplores the fact that the Libyan government has not yet responded effectively to the above requests to cooperate fully" and then "determined," in 748, that Libya's "continued failure to respond fully and effectively to the requests ... constitute[s] a threat to international peace and security."

The sanctions imposed by Resolution 748 prohibited air travel to or from Libya and arms sales to Libya and asked other governments and IOs to reduce the size of Libyan diplomatic delegations. Resolution 883 froze some Libyan assets abroad and halted the transfer of oil technology with Libya. Significantly, neither resolution included restrictions on the purchase of Libyan petroleum itself or affected assets abroad concerned with oil imports and exports. Despite the fact that the Libyan economy was heavily dependent on oil revenue-crude petroleum accounted for 85 percent of Libya's dollar-value exports in 1991-the Security Council did not interrupt this trade directly because of the significance of Libyan oil exports to several major European countries, notably Italy, Spain, Germany, and France. ${ }^{30}$ Italy acquired about one quarter of its oil imports from Libya. (Several governments, including the United States and UK, imposed unilateral, national-level oil embargoes against Libya as early as the mid-1980s.) ${ }^{31}$ With the absence of oil and oil revenue from the UN sanctions regime, their effect was not as comprehensively devastating to the Libyan economy as the post-1991 sanctions were to the Iraqi economy. However, the sanctions did impose significant costs on the Libyan government and population and had an enormous impact on the status and pres-

29. For details of the joint U.S.-UK statement of 27 November 1991, giving the four demands, see The Independent (London), 28 November 1991, 1.

30. Trade date from International Trade Statistics Yearbook 1995, United Nations, 1996.

31. Oil imports to the United States were banned in 1982 and comprehensive U.S. sanctions began with Executive Order 12543, 7 January 1986. Britain imposed sanctions in April 1984, and the EU instituted a ban on arms transfers to Libya in 1986. 
tige of the government in its dealings with IOs and other governments. ${ }^{32}$ Removing the sanctions and returning to a more normal relationship with the major Western economies was the central goal of Libyan foreign policy for nearly a decade. James Rubin, spokesperson at the U.S. Department of State, said in 1998, "It is their only international diplomatic exercise, as far as I can tell ... to go around and seek assistance from other governments in getting the sanctions lifted." 33

\section{The Sponsors' Arguments}

Security Council sanctions under Chapter VII of the Charter are legally binding on all member governments of the UN, but in practice sanctions rely heavily on their legitimacy for effective implementation by states. The Council cannot force governments to implement the policies that would make sanctions effective, and so it must rely on the self-motivated compliance of states. Often, the mere legal compulsion to obey the Council is not enough to ensure that states comply and the proponents of Council action go further in the giving of reasons for compliance. The authors of Council action generally do more in an effort to show that the Council's claim to be the collective spokesperson for the international community is justified. The Council deploys a variety of community resources to persuade the relevant audience of third-party states that the sanctions are legitimate. As with all symbolic resources, the legitimacy of sanctions must be carefully constructed by the Security Council. This takes place in and around the Security Council as the matter is debated and support is rallied. ${ }^{34}$ Here, the symbolic resources of the Council are put to use by the proposers of the sanctions to build perceptions of legitimacy in the new sanctions regime. The Libyan sanctions regime was promoted by the United States, the UK, and France, and built up over the course of two years.

Two periods of discussion are most relevant, one consisting of the debates that end with Resolution 731 on 21 January 1992; the second, the debates on Resolution 748, passed on 31 March 1992. Resolution 731 essentially called on Libya to "immediately provide a full and effective response" to the earlier four demands made public by the United States and the UK the previous autumn. There was no mention in the resolution of further action should Libya fail to comply, and it did not specify what Charter provisions it was relying on for its authority. It did contain a statement that international terrorism "constitute[s] a threat to international peace and security," which is important Charter language for justifying Council involvement in an issue, but this reflected the inability of the sponsors to negotiate a more direct reference to Chapter VII.

32. Libya's claims of damage are reported in UN Document S/26139, inter alia. Also see Niblock 2001. For a journalistic report, see Viorst 1999.

33. Federal News Service, 21 July 1998.

34. Hurd 2002. 
It was an important goal of the three sponsoring states (the United States, the UK, and France) that the vote on Resolution 731 be unanimous to strengthen the symbolism of the decision. They delayed introducing the proposal to the Council from December 1991, when it was informally agreed upon, to January 1992, to allow the two-year terms of Cuba and Yemen on the Council to expire, thus removing two likely "no" votes. The negative votes of nonpermanent members such as Cuba and Yemen of course do not matter from a legal standpoint (unless they prevent the necessary nine affirmative votes for a decision), but unanimity is a powerful rhetorical tool in the effort to present the Council as embodying the voice of the "international community." Yemen, it is interesting to note, did figure in the process in the end. Under the procedural rules of the Council any UN member can ask to be heard in the chamber and this request is almost automatically approved. ${ }^{35}$ Yemen requested and was granted time to speak as a nonmember of the Council during the debate on 731 and made a statement that closely paralleled Libya's arguments against the sanctions. Presumably this was something like the same statement it would have made as a sitting nonpermanent member. The content of the statement mattered less to the United States and the UK than did the fact that Yemen's institutional status had changed, so that it could no longer threaten the unanimity sought by the sponsors. The fact that the vote was indeed unanimous became an important reference point in subsequent discussions of the resolution. Immediately after the vote, the U.S. Representative to the UN stated that unanimity showed that "the voice of the international community is clear and determined." 36 This was repeated in some form in most prosanctions statements thereafter.

After weeks passed without the most visible of the demands in Resolution 731 being met (those on turning over the two suspects), the United States and the UK drafted a resolution calling for mandatory limited economic sanctions against Libya, and invoked the legal force of Chapter VII of the Charter. Most sanctions programs in the prior history of the UN have not been explicitly founded on the authority of Chapter VII. ${ }^{37}$ This draft provoked significantly more controversy than did Resolution 731 and required that the sponsors (the two drafting states plus France) lobby Council members and other states more strenuously. This lobbying centered on three rhetorical themes: (1) the threat to international peace and security posed by the potential proliferation of terrorism, (2) the adherence to well-established community standards on procedural justice, and (3) the need to promote and enforce respect for legitimate IOs. These three strands of argument established the themes of legitimation, which would subsequently be referred back to by defenders of the sanctions to justify their continuation.

The first theme of justification was important because a threat to international peace and security rationalizes the Council as the appropriate forum for dealing

35. See Bailey and Daws 1998, 154-59, for discussion of Article 32 of the Charter and Rules of Procedure 37 and 39.

36. UN Document S/PV.3033.

37. Bennett 1991, 138-39. 
with the issue. Terrorism has not previously been identified as within the Council's ambit. Article 24(1) of the Charter states that "Members confer on the Security Council primary responsibility for the maintenance of international peace and security," and while there is much discussion about the meaning of the qualifier "primary," 38 it is generally understood to mean that the Council is empowered to act whenever, but only when, a threat to international peace and security can be found. ${ }^{39}$ The U.S. representative argued in the Council that terrorism constitutes such as threat, and therefore it "fully justifies the adoption by this Council of measures pursuant to Chapter VII of the UN Charter." ${ }^{40}$ Sir David Hannay for Britain emphasized the global nature of the threat by noting that the two airplane bombings killed citizens of more than thirty countries: "The whole world has an interest in combating terrorism." Identifying a global threat to international peace and security was intended to preempt the arguments by Libya and others that the dispute was either a legal one (regarding extradition law, aviation treaty law, or conflict of jurisdictions), or a bilateral one between Libya and each of the sponsors. The British member made this explicit, suggesting that Libya's recourse to the International Court of Justice (ICJ) was in fact "directed at interfering with the exercise by the Security Council of its rightful functions and prerogatives under the UN Charter.... Any other view would undermine the primary responsibility for the maintenance of international peace and security." 41

The second area of justification of the sanctions centered on the strict following of procedural justice in their formulation and implementation. Thomas Pickering, the U.S. representative, made clear the sponsors' contention that the sanctions met the relevant standards in international law and norms (that they be proportionate, compassionate, and a last resort): "The means chosen in this resolution are appropriate; these sanctions are measured, precise and limited. They are a multilateral, non-violent and peaceful response.... They are the response prescribed in the Charter as the appropriate next step.... They are tailored to fit the offence" 42 The British representative said the "sanctions themselves are tailored precisely to [the] objective," and the French called them "balanced and appropriate ... selective and fitting." In addition to being "appropriate" the sponsors emphasized the humanitarian exemptions in the sanctions, including provision for permitting flights "on grounds of significant humanitarian need" if approved in advance by a com-

38. For instance, it is this qualification that was used to justify the Uniting for Peace resolution of the General Assembly in 1950, which claimed an implicit secondary obligation for the Assembly to act on matters of international peace and security as a result of the Council's primary responsibility.

39. Of course, in the manner of institutionalized practices, the repeated use of this justification by the sponsors of the resolution has contributed to its own legitimacy and institutionalization, so that subsequent discussion of the purview of the Council has been cast in these terms. See, for instance, Reisman 1993.

40. UN Document S/PV.3063. This began the precedent, used most notably by the Council after 11 September 2001, that "international terrorism" is automatically within the jurisdiction of the Council. For elaboration, see Kirgis 2001.

41. UN Document S/PV.3063.

42. Ibid. On sanctions in international law, see Bowett 1972. 
mittee of the Council. This was intrepreted by the sponsors to include flights for the hajj pilgrimage.

Finally, the sponsors promoted the justification that whatever the substance of the original resolution, it had been duly passed by the Council and had the force of law, and that Libya was therefore flouting the collective will of the international community by ignoring it. This justification provided a lever to move those states that may have had doubts about the merits of the Council's case, but nevertheless thought of themselves as on the side of international norms and law. The Hungarian representative, for instance, said the escalation to sanctions in Resolution 748 was needed to defend "the credibility and authority of the UN ... [and] to ensure compliance with its own resolutions." ${ }^{43}$ A state that is prepared to ignore the Council, as Libya was held to be doing, was in itself taken to be a threat to the international order, whatever the origins of the original dispute between the Council and the state. The sponsors later spoke of Libya's refusal to comply as "defiance of the will of the international community." ${ }^{44}$ The U.S. representative brought in other international institutions, nodding at the "efforts by the SecretaryGeneral, the League of Arab States and indeed many others to bring about Libya's compliance." ${ }^{45}$ These references to respected international institutions reinforced the desired image that the international community in all its institutional manifestations was standing opposed to the government of Libya on this issue. It was here that the unanimous vote on Resolution 731 was heavily played by the sponsors of 748, because it strengthened the argument that the dispute set Libya against the rest of the "international community."

Also revealing about these arguments was the concern with establishing a reputation of resolve for the Council, or for its dominant members. The U.S. representative repeatedly emphasized the "important message" being sent by the Council in supporting sanctions: that the Council "is prepared to take concerted political action against the continuing defiance of international obligations," and that it is "prepared to back up its own words with action." 46 In language similar to the Hungarian statement above, Ambassador Pickering went on to say, "That message is the surest guarantee that the UN Security Council, using its specific, unique powers under the Charter, will preserve the rule of law and ensure the peaceful resolution of threats to international peace and security, now and in the future." The behavior of the sponsoring states as sanctions continued through the 1990s was strongly conditioned by their preconceptions about the importance of a reputation for "resolve." This is consistent with others' observations that U.S. foreignpolicy makers believe strongly in the value of appearing resolute to outsiders. ${ }^{47}$

43. UN Document S/PV.3063.

44. UN Document A/48/314; also see UN Document S/26304.

45. UN Document S/PV.3063.

46. Ibid.

47. See Weldes 1999; Mercer 1996; and O’Neill 1999. 
There is little empirical evidence that this operates in the way that leaders believe, yet it is a recurring theme in the rhetoric of American politicians. ${ }^{48}$

\section{Libya's Response}

The sponsors' justifications for the sanctions centered on the threat to international peace and security, the legitimize power of procedural justice, and the dangers of rewarding disrespect for IOs. Libya's response, in turn, was to challenge each of these themes on its own terms by presenting an alternate image of the relation between the sanctions regime and the international community, one in which Libya appeared as the defender of liberal internationalism and the United States and the UK were the "outliers." It sought to undermine the widespread belief that it was an "outlaw" by showing evidence of a scrupulous adherence to international standards, and by showing the sponsors' failings of those standards. In the end, the progress of Libya's campaign and the stress it elicited in the sponsors created a tension in the position of the sponsors. The United States and the UK increasingly had to choose between divergent goals: defending the legitimacy of the Council or maintaining enforcement of the sanctions. Eventually, a growing disrespect for the sanctions among third-party states threatened to delegitimize the Council as it continued to demand respect for its resolutions.

The history of the external relations of Libya since the sanctions were imposed shows a concerted effort to appeal to accepted international practices and associate them with the Libyan government in the service of delegitimizing the sanctions in the eyes of influential states and organizations. The government attempted to reduce the appeal of sanctions to other states by engaging in rhetoric that showed the Council's position to be unrepresentative of the will of the international community at large and unreflective of the community's professed values. Libya did not attempt to say that the Council resolutions against it were irrelevant or inconsequential, or that the Council itself was illegitimate or should be ignored. Instead, it used the language of liberal internationalism to provide a reinterpretation of each legitimizing claim by the United States and the UK, seeking to undermine the inclination of many states to accept by default the interpretation provided by these two strong actors.

Libya's "campaign" can be divided thematically into three more specific efforts, directed at precisely the justifications given by the United States and the UK in trying to legitimize the sanctions in early 1992. Libya's representatives contended, over the course of several years, that (1) the sanctions regime violated norms of procedural justice recognized in international law and in the domestic legal systems of most states, including the United States and the UK; that (2) sup- 
porting the sanctions constituted disrespect for accepted IOs and the wishes of the international community, rather than respect for them; and finally that (3) such disrespect was itself a threat to international peace and security. None of these claims countered the basic empirical theory of legitimation that was implicit in the U.S.-UK position, namely that the legitimacy of rules comes from a consideration of both their procedural correctness and their consequentialist impact. Indeed, the Libyans seemed to agree with this model of legitimacy and use it to found their claims. However, on each point the Libyan strategy used these liberal internationalist norms to delegitimize the Council's decisions and undermine their power. The repeated use of these arguments and the manipulation of the procedural rules of international institutions forced the United States and the UK to respond continually and in a variety of settings to the contention that the sanctions violated the very norms by which they were justified. Eventually, this created a situation where the sanctions had to be sacrificed in the interest of preserving the legitimacy of the Council itself.

\section{Procedural Justice}

The Libyan government made several arguments to undermine the sponsors' claims that procedural justice contributed to the legitimacy of the sanctions. Libyan statements referred repeatedly to the fact that punishment in the form of sanctions was imposed before the matter was fully investigated "through judicial channels," 49 before the United States and the UK had presented "supporting evidence or proof" to the Libyans, and even while the sponsors were asking Libya (in Resolution 731) to disclose the documents and witnesses in its possession..$^{50}$ In particular, the latter point implied that U.S. and UK investigators had not yet been able to consider all relevant documents. Placing punishment ahead of comprehensive judicial hearing, they argued, violated the fundamental norms by which most domestic judicial systems operate as well as accepted international judicial practice. This was linked, in Libyan statements, with repeated references to the humanitarian costs of the sanctions program, emphasizing the toll that was being exacted before official judgment. ${ }^{51}$

The central violation of procedure on which Libya relied was the resolution's bypassing of the Montreal Convention on Civil Aviation. ${ }^{52}$ This treaty, enacted in 1971 and ratified by all the major players in the conflict, was intended to "arrive at a generally acceptable method of dealing with alleged perpetrators of acts of

49. UN Document A/48/PV.20, 5.

50. UN Document S/PV.3033.

51. For instance, see UN Document A/48/PV.20. Also see UN Documents S/26139; S/24428; and S/1994/921.

52. Formally the Montreal Convention on the Suppression of Unlawful Acts Against the Safety of Civil Aviation, 23 September 1971. 
unlawful interference with aircraft." 53 The Convention holds that a state that finds itself in possession of an individual who is alleged to have committed an offence of air terrorism "shall, if it does not extradite him, be obliged, without exception whatsoever ... to submit the case to its competent authorities for the purpose of prosecution." 54 The choice on extradition lies with the state holding the suspect, and in the absence of an extradition treaty between a state holding a suspect and a state wishing to try him or her, the former "may at its option consider this Convention as the legal basis for extradition in respect of the offences." Further, "Extradition shall be subject to the other conditions provided by the law of the requested State." ${ }^{55}$ If there arises a dispute about the interpretation of the Convention, Article 14(1) states "Any dispute between two or more Contracting States concerning the interpretation or application of this Convention ... shall ... be submitted to arbitration." If that fails, the dispute may be referred to the ICJ.

Libya contended that it had fulfilled its obligations under the Montreal Convention by investigating the suspects itself and thus that the Lockerbie conflict constituted a dispute under the terms of the Montreal Convention. It requested international arbitration and then ICJ involvement to certify its cooperation. The constant effort to cast the dispute in legal terms was in an effort to demonstrate to states considering complying with the sanctions that being "law-abiding" in the international context did not necessarily mean automatically following the Security Council, even in the face of Articles 24 and 25. Because the question was debatable on the law, Libya said, a legal forum should be used until it is resolved. This separated cleanly the responsibilities of the Council and the ICJ. Libya said in 1992, "If there is a conflict of jurisdiction, it is of a legal nature and international law and the relevant international conventions set out the concrete ways and means to solve it... There can be no doubt that this is a purely legal question. Neither can there be any doubt that therefore the Security Council is a forum that is not competent to consider the question." 56

The United States and UK, on the other hand, sought to prevent the issue from taking on the rhetoric of a legal dispute. Protracted debate on legality and illegality would take the matter away from the Council, where the sponsors' were relatively strong, and give it to institutions that were less "predictable" from their point of view. However, it is significant that the sponsors' were not free to simply ignore these Libyan appeals to international law: each challenge had to be met on its own terms and rebutted, since it was based on a rereading of the very norms and standards on which the United States and the UK were relying to justify the sanctions. Thus the United States and the UK participated in the ICJ cases, accepting the risk of adverse judgments, because to ignore them would contradict the

53. Reser $1998,819$.

54. Montreal Convention, Article 7.

55. Montreal Convention, Article 8(2).

56. Libya at the Security Council before the vote on Resolution 741, UN Document S/PV.3033. 
rhetoric of procedural justice they sought to promote. ${ }^{57}$ Indeed, more generally, the United States has a poor record of winning cases at the ICJ and yet continues to represent itself there vigorously. ${ }^{58}$ This practice should be recognized as an effort by the United States to demonstrate its respect for the rule of law in international politics, as well as being part of a response to the particular claims made in specific cases.

\section{Respect for International Organizations}

Libya made several efforts to show that its position was supported by, and in support of, various respected IOs to create the impression that it was the United States and the UK that were out of step with the international community. Libya, they argued, was part of and supported by the "mainstream" of international opinion. This effort took several forms.

Libya played up its participation as a good international citizen in the effort to limit international terrorism. At each opportunity, it publicized its condemnation of international terrorism, its steps to combat it, and its sympathy for its victims. In the debate on Resolution 731, Libya asserted that it condemned terrorism in all its forms and pledged its commitment to stamping it out from the world. ${ }^{59}$ Each year it marked the "painful anniversary of the destruction of Pan Am 103" with memorials, even going so far as to write individually to the families of those who died at Lockerbie to explain its position. ${ }^{60}$ In a 1999 speech, Qaddafi repeated this refrain: "We ... feel the same [sympathy] for the families of all the victims of the aircraft. What I want to say here is that the [families of the] Lockerbie victims have not shown malevolence toward Libya. On the contrary, they have always supported us and have thanked us for our positive attitude and stances." ${ }^{61}$ Qaddafi also regularly called for international conferences or special sessions of the UN General Assembly to "study the causes and dimensions of the [terrorism] problem." ${ }^{62}$ To verify Libya's distance from terrorist groups, he invited the UN secretary-general to send missions to Libya to confirm that it was not supporting activities linked to terrorism. ${ }^{63}$ Privately, Libya began providing the UK in 1992 with details of its aid to the Irish Republican Army (IRA). ${ }^{64}$

57. The UK and United States lost the argument at the ICJ that the Court had no jurisdiction. In 1998 the Court agreed with the Libyan argument that a "dispute" existed under the Montreal Convention and it was hearing the substantive arguments when, in 2003, the two sides jointly asked that the case be dismissed. Given the settlement of the Council sanctions by then, the ICJ agreed and removed the case from its docket in September 2003.

58. Bekker 1998.

59. UN Document S/PV.3033.

60. UN Document S/1997/991.

61. Speech on Libyan television in Arabic, 2 March 1999. Reprinted by BBC Summary of World Broadcasts, 4 March 1999.

62. UN Document A/48/PV.20, 5.

63. UN Document S/1996/609.

64. Niblock 2001, 45. 
Second, Libya publicized its willingness to engage with a range of IOs, as representatives of the international community, to help resolve the particular conflict at the center of the resolutions. Libya requested international arbitration as mandated under the Montreal Convention on Civil Aviation to mediate legal points between it and the United States and UK. On the question of the two suspects, Libya offered to produce the suspects to the UN Development Program office in Tripoli, or to the secretary general, or to the ICJ. In its willingness to cooperate with institutions other than the Security Council, Libya hoped to convince its audience of third-party states that it was not being recalcitrant with respect to the international community, as was claimed by the United States and the UK, but rather had a bilateral dispute with these two states, one which should be resolved through legal channels or arbitration. Its position was that its dispute was with the United States and UK and not with the Security Council or the community of states more generally.

Third, Libya also publicized evidence that the sanctions were being disrespected by reputable actors. Every time a state or organization violated the sanctions or publicly questioned their justification, Libya broadcast the information to as wide an audience as possible as a means of showing the Security Council to be out of step with the community. By 1998 Qaddafi's speeches on Libyan television and radio, and his diplomats' speeches at the UN and elsewhere, routinely included long lists of thank-yous and acknowledgments to the Organization for African Unity, the Arab League, the Gulf Cooperation Council, and individual states and leaders for their questioning of the sanctions regime. ${ }^{65}$ The rhetorical power of violations and criticism was so potent that Libya, on occasion, reported violations that were not in fact violations. For example, Libya called the visit of President Hosni Mubarak to Qaddafi in July 1998 a violation-in fact, the trip was approved in advance by the Security Council (although under the pressure of knowing it would probably take place anyway). ${ }^{66}$ This power was understood on the sponsors' side and the U.S. government chose at times to ignore some violations for fear of increasing Libyan support by pressing the matter at the Sanctions Committee of the Security Council. ${ }^{67}$ At the same time, Libya sought to conceal other kinds of violations, such as an active smuggling program via cooperative foreign companies. Although no doubt useful materially, this activity did not serve the rhetorical goals that disrespect of sanctions by other parties did, and indeed worked against them. Thus violations by Libya were concealed, while violations by others were publicized.

Finally, Libya took careful advantage of the openings available to it under the procedures of the Security Council and other IOs. The Council's operating rules

65. See, for instance, Qaddafi's speech of 2 March 1999 reprinted by BBC Summary of World Broadcasts, 4 March 1999. Also see BBC Report, 11 June 1998; BBC Report, 6 August 1998; and The Guardian, 11 September 1998, 16. For speeches at the UN, see UN Document A/48/PV.20.

66. The Guardian, 10 July 1998, 16.

67. One such instance was reported by the Washington Post with respect to Libya's sending pilgrim to the hajj to Saudi Arabia without first earning permission from the Committee. Washington Post, 21 April 1995, A30. 
on sanctions call for a review every four months by a Council committee of the whole. This provided Libya with a regular platform for making its case within the Council. It never failed to do so, and it carefully submitted reports to the Council in advance of each meeting detailing each of the three factors mentioned above: the absence of procedural justice, the damage done by the sanctions, and critical statements by "respected" voices (states, noted individuals, and IOs). ${ }^{68}$ In addition to the cases filed with the ICJ, Libya continued the legal theme with petitions for the arrest of U.S. political and military officials over the 1986 bombing of Tripoli and Benghazi. Mirroring the domestic U.S. grand jury procedure that began the pressure to extradite the two Libyan suspects, ${ }^{69}$ Libyan prosecutor Mohammed Abdel-Wahab issued arrest orders in 1998 for the former director of the U.S. Central Intelligence agency (CIA) William Casey, U.S. National Security Advisor John Poindexter, and seven others. He also suggested that, if all else failed, Libya would "resort to the Security Council to get the accused." 70

As I show below, the sincerity of these statements is beside the point. What matters is that they were well-targeted and the United States and the UK felt compelled to respond to them with principled defenses of the sanctions regime.

\section{International Peace and Security}

The language of threats to "international peace and security" is important in international law because it is the enabling phrase that the UN Charter uses to define the powers of the Security Council. It is generally included in Security Council resolutions to justify coercive measures. As such, it was vital to U.S. and UK justifications for sanctions against Libya: "Libya's involvement in these acts of terrorism indicates a serious breach of international peace and security" said Pickering. ${ }^{71}$ However, the language is equally available to other actors than the great powers, and in these other hands it can be used to achieve different ends. This is a central fact of the public quality of symbols and institutions: they cannot be entirely monopolized by the strong without threatening the legitimacy on which they are based. Libya's speeches in the Council and elsewhere supported the Council's authority to take action against "threats to international peace and security" and so supported the Council as an institution. It also defined such threats in traditional terms as any coercive action that did not have the support of the international community. ${ }^{72}$ However, Libya then turned the tables on the United

68. These and other Libyan communications to the Security Council and the UN secretary-general are documented in the annual Yearbook of the United Nations.

69. The original indictment was issued by the District Court for the District of Columbia, 14 November 1991.

70. Boston Globe, 31 December 1998, A4.

71. U.S. Ambassador Pickering to the Security Council, UN Document S/PV.3063.

72. See, for instance, Libya's statements before the vote on Resolution 731 in UN Document S/PV.3033, and on Resolution 748 in UN Document S/PV.3063. 
States and the UK by taking the two sets of evidence just described (the alleged lack of procedural justice and of community support) to represent the sanctions themselves as the threat to international peace and security, on the grounds that the resolutions were not widely and actively supported by the community. To the extent that this argument was persuasive to third parties, Libya could contend that the threat that the Council should be concerned with came from the sponsors of the sanctions resolutions and not from Libya itself.

\section{Compliance, Defection, and the 1998 Compromise}

The sanctions on Libya were at first relatively well respected, even among states that one might expect not to support them, including Egypt, Iran, and several north African states. I list several reasons for this. The first is that the sanctions regime was itself largely symbolic. It did not include controls on Libya's oil exports, which would be the logical target if the international community wanted to seriously impinge on Qaddafi's interests. The ban on air travel and the limits on diplomatic representation were no doubt an inconvenience, but it was their symbolic effect in casting the Libyan government as an "outlaw" that the sanctioners were aiming for. By contrast, the controls on Libya's overseas financial instruments did hit at resources of real consequence, but these controls took effect after Libya had had time to rearrange its finances so as to minimize the damage. ${ }^{73}$ Second, the sanctions were respected in part because the sponsors were willing to use (or threaten to use) their leverage against third-party states to gain their acquiescence. Finally, the sanctions earned some respect from the fact that they were duly promulgated by the Security Council, and that this procedural legitimacy is in itself an argument in favor of compliance. In all, international respect for the sanctions was judged to be relatively good in the early years. ${ }^{74}$ Libya's international trade was disrupted: even without oil in the sanctions regime, Libya's total exports fell in the years immediately after the sanctions, by 11 percent in 1992 and 24 percent in 1993. ${ }^{75}$ Libya also ended up selling or drastically restructuring its foreign assets and firms. ${ }^{76}$ In addition, it became difficult to pursue the normal processes of diplomacy, and Libya came to rely on an informal network of middlemen, agents, foreign lawyers, and even some unknowing others to communicate with other governments. ${ }^{77}$ This intermediating collection of advisors and opportunists was blamed by the secretary general of the UN for

73. Rose 1998. Also see The Observer, 27 February 1994, 22.

74. Rose 1998. Bray calls the earlier unilateral American sanctions "relatively ineffective" and says the multilateral UN sanctions "more likely to be effective." Bray 1996.

75. International Monetary Fund, Direction of Trade Statistics, 1997.

76. Vandewalle 1998, 146. See also The Guardian, 27 February 1994, 2.

77. Washington Post, 2 October 1993, A12. 
making resolution of the conflict more, rather than less, difficult. ${ }^{78}$ Despite periodic U.S. and UK complaints that some states were not abiding by the sanctions, for the first several years they were in fact well respected. ${ }^{79}$

Qaddafi's many proposals for "compromise" in various forms were rejected by the sponsors, who insisted on what they considered to be the essentials of the original demands: that the suspects appear before a UK or U.S. court. The consistency displayed by the sponsors was in part motivated by a concern for the reputation of the Council and its backers. The United States and the UK were heavily invested in the rhetoric laid out to legitimize the sanctions and were extremely reluctant to give recognition to any Libyan overtures for compromise. Accepting any compromise was feared to provide "face-saving for Qaddafi" and to show the sponsors to be irresolute. ${ }^{80}$

The situation began to change in small increments as the violations by thirdparty states started to accumulate. From Libya's early probing of the limits of the sanctions in 1995 by sending planes to Mecca for the hajj, ${ }^{81}$ and the occasional flights from Tripoli to Egypt in 1996, ${ }^{82}$ isolated violations of the flight ban started to show an underlying discontent with the sanctions among many states, particularly in Africa. These violations increased in frequency throughout 1996 and 1997, although they never became anything more than isolated. In May 1997 the U.S. State Department accused Niger and Nigeria of conducting unauthorized flights to Tripoli. ${ }^{83}$ The pace of violations accelerated in 1998. Two Italian planes reportedly arrived in April 1998, marking the first European violation. ${ }^{84}$ Then in June 1998 the Organization of African Unity passed a resolution approving that its members could ignore the flight ban as of that September. ${ }^{85}$ This institutional declaration spurred an increase in flights-violations. Sudan, Chad, Niger, Mali, and the Central African Republic each flew into Tripoli in September, to celebrate the anniversary of the Libyan revolution, and the Gambia sent a flight a few days later. ${ }^{86}$ President Mubarak of Egypt visited in July - he secured UN approval before his trip, and so it was not a violation, but in the context of the other violations it was read as a signal of Egypt's impatience with the ban. ${ }^{87}$

78. Boutros-Ghali 1999.

79. U.S. and UK complaints are documented in a 1996 report, S/1996/606, including that Libyan Airlines offices remained open in several cities and that Libyan diplomatic representation had in some locations increased since 1992.

80. International Herald Tribune, 22 July 1998, 1.

81. See New York Times, 6 April 1995, A3; and Washington Post, 20 April 1995, A34.

82. New York Times, 6 July 1996, 4.

83. U.S. Department of State, Press Statement, 13 May 1997. Available at /secretary.state.gov/www/ briefings/statements/970513a.html . Accessed 10 March 2005.

84. Washington Post, 25 April 1998, A12.

85. This was communicated to the Security Council in UN Documents S/1998/549 and S/1998/597.

86. The Guardian, 11 September 1998. Gambia's flight was reported to be a form of a thank-you for Libya having paid that country's back-dues to the UN. There was also a report that Libya paid Malawi's back-dues in 1999, for which Malawi expressed support for Libya in the face of "U.S.British intransigence." BBS Summary of World Broadcasts, 6 February, 1999.

87. The Guardian, 21 July 1998, 1. 
These violations of the flight ban did not contribute a real material benefit to the government of Libya-there was no evidence that the flights were carrying significant cargoes of prohibited industrial or military goods. So, although the violations were real in the sense that they contravened the literal prohibitions in the resolutions, there were for the most part symbolic in that they simply communicated the states' dissatisfaction with the sanctions. Of course, symbolic status can turn into material benefit-which is precisely what happened. The significance of the decaying flight ban is that it put pressure on the sponsors of the sanctions to somehow reconcile the position of the Council with the "facts on the ground." This pressure came from below, from the "rank-and-file" of the UN, whose cooperation is essential for making sanctions regimes work.

The growing gap between the declared position of the Security Council and the actions of many states became a threat to the perceived legitimacy of the Council. There was a disconnect between the authoritative words of the Council and the behavior of its audience. The Council could not force states to participate in the sanctions regime and was increasingly seen as holding a position that was out of touch with the prevailing currents of the international community. This is a dangerous position for an institution to occupy, and in the case of the Council it threatened to reveal the Council as a surrogate for the United States and the UK. If this happened, it would undermine the Council's carefully constructed corporate identity and potentially undermine its power in other situations. This point was well made by the Canadian ambassador to the UN who said, in 1998, that for the Council to exercise "leadership" it needs a "followership," and that in the case of the Libyan sanctions, this was increasingly lacking. ${ }^{88}$ The ambassador made clear that it would be dangerous for the "credibility" of the Council if it insisted on maintaining the sanctions after the point at which large sections of the UN membership had ceased supporting them. Similarly, the secretary general of the UN said that he realized early in his tenure that Libya's strategy was gradually winning international support: "I realized that if we didn't find a way forward [the sanctions would lose all legitimacy]. [By] rejecting every Libyan proposal [the United States and $\mathrm{UK}]$ had boxed themselves into a situation of being the stubborn negative ones." 89

The "way forward" was an agreement reached in 1998 under which the suspects would be tried in a third country, where Scottish law would be applied. The final version of the compromise specified that Scottish law would be applied at a court in a disused U.S. military base in the Netherlands, Camp Zeist, which for the purposes of the trial would be transformed into Scottish territory. ${ }^{90}$ The suspects were transferred in the custody of the UN, and protected by the UN

88. Remarks to the Security Council, cited in International Documents Review, Vol. 9, No. 37, 26 October 1998, 1.

89. Kofi Annan, cited in New York Times, 7 April 1999, A8.

90. Details on the legal and security arrangements can be found at http://www.law.gla.ac.uk/ lockerbie/index.cfm. Some colorful details on the transformation are provided in New York Times, 1 August 2000, A4. 
while in the Netherlands. The trial was presided over by three Scottish judges and no jury, according to Scottish procedures, and with any prison time being served in Scotland. ${ }^{91}$

The compromise rescued the sponsors from the worst of their dilemma: trying to defend the Security Council's legitimacy while the sanctions were being systematically violated. It also rescued Libya from the sanctions: they were suspended in April 1999 and removed by Resolution 1506 in 2003. However, it is interesting that the basic formula that was adopted in the compromise was first proposed by Qaddafi as early as 1994. At that time, on the sixth anniversary of the Lockerbie explosion, Libya took out full-page ads in several leading newspapers to propose that a Scottish court conduct a trial of the two at the ICJ in the Hague. ${ }^{92}$ The Arab League began championing the idea from May 1996 after its SecretaryGeneral Esmat Abdel-Meguid visited Libya. ${ }^{93}$ Other variants were put forward even earlier, including having Scottish prosecutors before the ICJ or at an ad hoc international tribunal. ${ }^{94}$

At the time of its first airing, the United States and the UK called this proposal a "nonstarter" and said "We will not be satisfied with half measures [and] we reject offers to negotiate the extent of its compliance with UN Security Council resolutions." ${ }^{95}$ A senior U.S. State Department official said "There can be no compromise on the need for trying the suspects in a Scottish court under Scottish law. We are absolutely opposed to any alternative trial venue." ${ }^{96}$ Their position began to change as the rate of defections from the sanctions rose. By 1998 the cohesion of the prosanctions coalition was coming apart, leaving the Council vulnerable to seeming irrelevant.

The change in the sponsors' position came about because of the decrease in respect for the sanctions by third-parties. By the time the tenth anniversary of the bombing was approaching, the United States and the UK were apprehensive, on the one hand, of having their hard-line strategy appear to the public to be a failure and, on the other, of having large numbers of states and organizations defect from the regime. The UK was the more willing partner, and it brought a somewhat reluctant United States along. As a result, the two countries began calling the Scottishlaw/Dutch-venue compromise their own and challenged Qaddafi to meet it. Once the United States and the UK switched sides and began supporting the compromise, they began also to cite its international support as contributing to its (and to their) legitimacy. In the letter to the UN secretary general in which they announced their support for the measure, the Permanent Representatives of the United States

91. Details in Niblock 2001.

92. Washington Post, 22 December 1994, A28. The ad ran in the Post on 21 December 1994.

93. The Herald (Glasgow), 22 May 1996, 12.

94. For the "Black Plan," of a Scottish prosecutor before the ICJ, see The Independent (London), 24 January 1994, 10. Also see Christian Science Monitor, 9 November 1994, 1.

95. First quote is unattributed in Christian Science Monitor, 9 November 1994, 1. The second quote is by Michael McCurry, State Department spokesperson, in the Washington Post, 22 December 1994, A28.

96. Unidentified official, Christian Science Monitor, 9 November 1994, 1. 
and the UK stated, "This initiative represents a sincere attempt by the Governments of the United Kingdom and the United States to resolve this issue, and is an approach which has recently been endorsed by others, including the Organization of African Unity, the League of Arab States, and Movement of Non-Aligned States and the Organization of the Islamic Conference." 97 This exactly mirrors the earlier efforts of Libya to legitimize their position by reference to its community support.

The end result was not a clear victory for either side. It required both sides to move from their initial positions and to accept provisions that they once said they would not. In that, it was a classic compromise. Thus it cannot be said that Libya's strategy was entirely successful. However, it did provide to third parties an alternative interpretation of liberal internationalism and give a principled defense for ignoring the sanctions. The transition from "resoluteness" to "compromise" on the part of the sponsors shows the uncomfortable position they found themselves in as the defenders of the legitimacy of the Security Council. The first preference of the sponsors of Resolution 731 would probably have been to continue the sanctions until the demands of resolution were fully met (as evidenced by their earlier rejection of the same compromise). However, holding this position when many smaller states showed signs of abandoning the sanctions coalition would impose a cost on the legitimacy of the Council. By 1998 the sponsors were not willing to expose the Council to this danger.

The foregoing case suggests that there are two steps in the causal chain that links Libya's strategy of delegitimation to the ultimate compromise that ended the sanctions. First, Libya's use of liberal internationalist rhetoric emboldened states sympathetic to it and encouraged them to violate the sanctions. Second, these violations induced the United States and the UK to accept a more limited solution than they originally demanded, to avoid the Council defending a program that existed on paper only. Both steps are crucial to understanding the eventual outcome.

Evidence for the first step comes from observing both the pattern of which states defected and which did not and the manner in which the defectors went about defecting. Defecting states were those with little direct investment in liberal internationalist norms, namely nondemocratic African states, mostly small and with internal reasons to prefer to stand with Libya than with the United States and UK. Had Libya's claims been addressed directly at the liberal states in the international system, one might test the effect of those claims by examining for changes in the behavior of those states. But Libya did not address its claims that way. Defections happened among states that appeared to be originally only weakly attached to the sanctions so that a small change in the structure of incentives that they faced could be enough to tip the strategic calculus in favor of defection. Having a legal justification for defection reduced the political costs enough to change the balance for

97. Letter dated 24 August 1998 from the Acting Permanent Representatives of the UK and the U.S. to the United Nations Addressed to the Secretary-General, UN Document S/1998/795. See also Madeleine Albright's statement of the same day, cited in Murphy 1999, 174-79. 
those governments. The same change in the incentives faced by solidly liberal states did not cause an immediate chance in policy, because those incentives were further from the margin in the first place. Only when many illiberal states changed their positions did that pressure on liberal states accumulated.

The manner in which violations were performed also supports the interpretation that Libya's strategy affected these states' behavior. The eagerness of the violators to publicize their actions suggests that they did not believe they were breaking important laws or norms; quite the opposite, it shows that they believed that if pressed they could justify their actions as legitimate under prevailing international norms. Libya's efforts helped to provide them with that justification.

The second step in the causal chain connects these violations with the change in policy of the United States and UK. Evidence that the change came about because of concern with rising rates of defection is readily available in the contemporary accounts. ${ }^{98}$ As Niblock reports, by 1997 "the sanctions were becoming unsustainable. With African, and possibly Arab, governments intent on flouting the sanctions ... the sanctions regime might simply fall apart." "99 U.S. and UK decision makers were concerned that the rate of defection would continue to increase. Two moments in 1998 help to explain the particular timing of the policy change: the Italian violations in April and the anniversary in December. Both moments were interpreted as giving added legitimacy to Libya's claims and so further undermining the sanctions coalition. Italy's decision was important because it signaled the leading edge of European impatience, and the anniversary was important because it was expected to bring new calls from victim's families for more "flexibility" in the U.S.-UK position. ${ }^{100}$ The compromise was settled in fall 1998, before the anniversary.

To be clear on the limits of my claims, I want to consider two competing interpretations of the driving force behind the compromise. Both alternate explanations take issue with the argument that I have presented although at different levels: one disputes the role of liberal internationalist norms, and the other disputes the very premise that there was a compromise at all.

First, on the existence of a compromise itself: Comparing the 1998 outcome to the original demands of 1991, the United States and the UK got most of what they wanted-trial of the two suspects in court, compensation for the victims' families, and a change in Libya's international behavior. This leads some to conclude simply that the United States and the UK won and that the sanctions were a success. If this is the case, then Libya's strategic use of Council norms was at best a losing effort and certainly not worth much attention. My argument disagrees with this interpretation on the grounds that Libya won several things of strategic value by virtue of its strategy. First, Libya forestalled turning over the

98. For instance, see New York Times, 1 November 1998, 8; and New York Times, 25 July 1998, B5.

99. Niblock 2001, 52.

100. Ibid., 51-52. 
suspects for several years, and this time is in itself valuable. Second, Libya bargained for and won written assurance that the judicial investigation would not go beyond the two suspects and so would not endanger superiors in the regime. Third, Libya won enhanced social prestige among important international groups. This prestige came in two forms: for many states in Africa, Libya earned status for resisting Western pressure for so long, while for many liberal states Libya increased its respectability by agreeing to and carrying out a solution apparently based on international law and IOs. The ultimate result was much friendlier to Libyan interests than would have been handing over the suspects in 1992, even though the damage from the sanctions was not negligible. In other words, it was a compromise; both sides could claim a limited victory.

The second interpretations concerns norms. One could accept that the outcome was a compromise but still disagree with the causal story about its genesis that I present. A strictly materialist version of events would suggest that Libya's reference to liberal internationalism made no difference to the outcome, and that the outcome would have been essentially the same in the absence of the use of symbols around the Council. This argument instead centers on a hypothesis about the increase in the costs to the United States and the UK of maintaining the sanctions over time and is generalized in arguments about "sanctions fatigue." Haass, among others, has argued that sanctions regimes have a natural tendency to erode over time and that the costs of maintaining an enforcing coalition rise. ${ }^{101}$ This gives rise to a kind of natural life cycle for sanctions regimes that is also observable in this case: initial high compliance gradually declines and ultimately leads to a moment of crisis as the prosanctions states must reassess their commitment to the regime. Although the mechanisms by which this is believed to work are not well spelled out, one suggestion is that over time policymaker attention and public emotion wane, leaving would-be violators of the sanctions increasingly free to ignore the rules.

The evidence in this article partly supports this conclusion: rising costs to maintaining the sanctions regime were indeed decisive in pushing the prosanctions states toward a compromise. But the nature of and change in these costs cannot be explained except with reference to the manipulations of liberal norms by Libya. By providing its allies with a set of arguments that liberal internationalism was on the side of violating the sanctions, Libya gave them tools by which to shift the onus back on the prosanctions states. The prosanctions states, to whom the selfidentity of being liberal internationalists was most important, were thus made responsible for responding to the reinterpretation of the norms. It is this response that grew costly and ultimately was not worth the investment. In the absence of Libya's use of norms, it would have been more costly for countries in Africa to violate the sanctions; some countries might still have done so, but at a greater cost to their reputations with the West. In the end, it is correct that the changes in the costs of maintaining the sanctions regime were crucial to the shift in policy of the 
United States and UK, but those costs were themselves driven by Libya's strategic manipulation of liberal internationalism.

It is not crucial to my argument that Libya's statements and promises regarding its commitment to international law or order be sincere. In fact, their sincerity is beside the point. What matters is how the audience reacts to the claims. Important states in the prosanctions coalition responded positively to Libya's frequent and public claims about liberal norms that the act of making them appears to have forced the United States and the UK to alter their behavior-first by defending the sanctions against new challenges and second by accepting a compromise solution. This is all the more interesting if the statements were indeed insincere, because then one sees the power of "mere rhetoric" to move governments. Libya was not a liberal state at the start of this episode, nor were those who began the sanctions violations liberal states in their domestic affairs. But in liberal symbols and institutions Libya found a powerful justificatory discourse that was significant to the self-identity of many powerful states in the system. This created internal ambiguity in these liberal states that could not be ignored by them.

\section{Conclusions}

The Libyan episode at the Council is instructive both for those interested in foreignpolicy making and those interested in theory. Regarding policymaking, the interpretation presented here of Libya's motives helps to understand Libya's behavior in recent years since the sanctions were removed. Attempting to normalize its relations with the West was a preeminent motive in Libyan foreign policy through the sanctions years and has continued since then. This has resulted in several noteworthy recent developments, including its support for the American "war on terror" in response to the 2001 terrorist attacks on the United States, its new willingness to publicize and end its weapons of mass destruction (WMD) programs, and its courting of international capital. While the Bush administration has attributed Qaddafi's shift on WMD to the implicit example carried in the U.S. invasion of Iraq, a more realistic interpretation is that Qaddafi has used the new U.S. interest in WMD to his advantage by trading away his now symbolically valuable weapons programs in exchange for favors from the United States and Britain. There is good evidence that Libya was not serious about maintaining its WMD arsenal and had begun to find it a burden; ${ }^{102}$ it had sought several times in 1999 and 2000 to bargain with the West over its weapons, but it did not find a receptive audience in Europe until 2002. The profile given to WMD in the U.S. case for war against Iraq made Libya's programs, well known to Western

102. See sources in "How Gadaffi Was Brought Back into the Fold," Financial Times, 27 January 2004, 17. Also see "Why Gaddafi Gave Up WMD," BBC News, 21 December 2003; and "The Iraq War Did Not Force Gadaffi's Hand," Financial Times, 8 March 2004, 21. 
intelligence, much more valuable a bargaining chip for Libya. One can now see, in the form of new diplomatic status, the payoff to Libya from this exchange. ${ }^{103}$

The fight at the Council over the Libyan sanctions illustrates three more general principles regarding the nature of power in the international system. First, it shows how central the concept of legitimacy is in IR. The strategies of both sides in the Libyan case, as well as the more basic goals that these strategies served, were essentially defined by legitimation and delegitimation. The United States and the UK brought the matter to the Council in the first place to seek what Claude called the "collective legitimation" of the UN for their policies, and the Libyan counterattack sought to disengage the policy from the legitimation. Unless one understands the power that states gain by having their policies legitimated by collective institutions, one cannot understand the strategic behavior of either side in this case.

Second, the central concern with legitimation among states gives rise to a moral economy of symbolic politics that structures the terms of political competition. Symbolic power can be extremely useful to states, and motivates such behavior as the American effort to win Council approval for the 2003 war on Iraq. The Libyan case illustrates how symbols can be powerful tools for states in international controversies, with each side making use of the symbols of liberal internationalism in an effort to win supporters to their cause. The pursuit of legitimation and delegitimation is conducted by either deploying or reinterpreting the symbols of legitimated institutions. Even for actors who do not themselves believe in the legitimation of the institution, there may be power to be gained by using its symbols - to the extent that others do believe in it, these will be effective instruments. This suggests a possible irony in that those individuals who hold a genuine commitment to a symbol might be in a position of relative weakness next to others who do not but who are willing to manipulate it strategically. There is greater freedom of action for the manipulator than for the true believer (although one should remember that one does not choose which of these categories to belong to).

Either way, a social order that is founded on the use of legitimated institutions is vulnerable to disruption from below when competing interpretations are promoted and begin to be adopted by the audience. Once the dominant powers have come to rely in part on a legitimated institution to provide order in the international system, they have set a difficult task for themselves: their influence thereafter relies on a perpetual effort to police and maintain the legitimacy of the institution. This often requires action and statements they would rather have avoided. Once hitched to the rhetoric of due process and community support, the sponsors could not ignore Libya's statements and actions that appealed to these same principles but interpreted them differently. As Scott says, "Any ruling group, in the course of justifying the principles of social inequality on which it bases its claims to power, makes itself vulnerable to a particular line of criticism. . . Every publicly given justification for inequality thus marks out a kind of symbolic Achilles 
heel where the elite is especially vulnerable." 104 This situation creates opportunities for others to challenge the status quo.

Finally, the Libyan episode shows that the distribution of material power among states is not necessarily a good guide for predicting the distribution of power in the symbolic economy of the system. The vulnerabilities inherent in rule based on legitimation mean that actors with little material power may have leverage in the symbolic field against those with great material capabilities. ${ }^{105}$ As a result, one may use the system's institutional channels for opposition. This puts the onus on those working within the system to respond thoroughly to each challenge. Failure to respond, or a response without due regard for the sensitivities of the audience, throws the charge of acting illegitimately back on those who have the strongest attachment to the rules in the first place, which can only help the opponent's cause. Evidence of this can be seen in the Libyan case. The repeated legitimations involved in justifying the Council since its founding, and in the defense of the sanctions themselves, have resulted in the strong states being committed to a set of rhetorical claims about procedural justice and due process that then become available for others to use against them. The symbols that activate the authority of institutions are available to all participants and their limits must be respected even by the strong. When the strong cross those limits, the power of the institution is threatened. It is for this reason that to call the Council "a kingdom of words," as did a former Lebanese ambassador to the UN, is not to denigrate it or suggest its inferiority to other, presumed, "kingdoms of action." The ambassador used that phrase as a term of respect for the Council, in recognition of the fact that at bottom political conflicts are fights over symbols and legitimation, and that the Council is a key location for their use. ${ }^{106}$

\section{References}

Bailey, Sydney D., and Sam Daws. 1998. The Procedure of the UN Security Council. 3d ed. Oxford: Clarendon Press.

Barnett, Michael, and Raymond Duvall. 2005. Power and International Politics. International Organization 59 (1):39-75.

Barnett, Michael, and Martha Finnemore. 1999. The Politics, Power, and Pathologies of International Organizations. International Organization 53 (4):699-732.

Bekker, Peter H.F. 1998. Questions of Interpretation and Application of the 1971 Montreal Convention Arising from the Aerial Incident at Lockerbie. American Journal of International Law 92 (3):503-8.

104. Scott 1990, 103, 105.

105. For an argument that the various modes of power are complementary, not competing, see Barnett and Duvall 2005.

106. Jean Krasno's interview with Ghassan Tueni for the Yale-UN Oral History Project, 1998. Transcript on deposit with Sterling Memorial Library, Yale University, New Haven, Conn. Claude made a similar point in Claude 1967, 88-90. 
Bennett, A. LeRoy. 1991. International Organizations: Principles and Issues, 5th ed. Englewood Cliffs, N.J.: Prentice-Hall.

Boutros-Ghali, Boutros. 1999. Unvanquished: A U.S.-U.N. Saga. New York: Random House.

Bowett, D. W. 1972. Economic Coercion and Reprisals by States. Virginia Journal of International Law 13 (1):1-12.

Bray, John. 1996. Sanctions: Sticks to Beat Rogues With. The World Today (London) 52 (8-9):206-8.

Buchanan, Allen. 2003. Justice, Legitimacy, and Self-Determination: Moral Foundations of International Law. Oxford: Oxford University Press.

Carpenter, R. Charli. 2003. 'Women and Children First:' Gender, Norms, and Humanitarian Evacuation in the Balkans 1991-95. International Organization. 57 (4):661-94.

Chayes, Abram, and Antonia Handler Chayes. 1995. The New Sovereignty: Compliance with International Regulatory Agreements. Cambridge, Mass.: Harvard University Press.

Claude, Inis L., Jr. 1967. Collective Legitimation as a Political Function of the United Nations. In The Changing United Nations, edited by Inis L. Claude. New York: Random House.

Connolly, William E. 1987. Modern Authority and Ambiguity. In NOMOS XXIX: Authority Revisited, edited by J. Roland Pennock and John W. Chapman, 9-27. New York: New York University Press.

Crawford, Neta. 2002. Argument and Change in World Politics: Ethics, Decolonization, and Humanitarian Intervention. Cambridge: Cambridge University Press.

Doxey, Margaret P. 1996. International Sanctions in Contemporary Perspective. 2d ed. New York: St. Martin's Press.

Drezner, Daniel W. 2000. Bargaining, Enforcement, and Multilateral Sanctions: When is Cooperation Counterproductive? International Organization 54 (1):73-102.

Epstein, James A. 1994. Radical Expression: Political Language, Ritual, and Symbol in England, 17901850. New York: Oxford University Press.

Fearon, James, and Alexander Wendt. 2002. Rationalism vs. Constructivism: A Skeptical View. In Handbook of International Relations, Walter Carlnaes, Beth Simmons, and Thomas Risse, 52-72. Thousand Oaks, Calif.: Sage Press.

Finnemore, Martha. 1993. International Organizations as Teachers of Norms: The United Nations Educational, Scientific, and Cultural Organization and Science Policy. International Organization 47 (4):565-97.

Finnemore, Martha, and Kathryn Sikkink. 1998. International Norm Dynamics and Political Change. International Organization 52 (4):887-918.

Gruber, Lloyd. 2000. Ruling the World: Power Politics and the Rise of Supranational Institutions. Princeton, N.J.: Princeton University Press.

Haass, Richard N. 1998. Economic Sanctions: Too Much of a Bad Thing? Policy Brief 34. Washington: Brookings Institution.

Hearn, Frank. 1975. Remembrance and Critique: The Uses of the Past for Discrediting the Present and Anticipating the Future. Politics and Society 5 (2):201-27.

Heath, Joseph. 2003. Communicative Action and Rational Choice. Cambridge, Mass.: MIT Press.

Hendel, Charles W. 1958. An Exploration of the Nature of Authority. In NOMOS I: Authority, edited by Carl J. Friedrich, 126-44. Cambridge, Mass.: Harvard University Press.

Hurd, Ian. 1999. Legitimacy and Authority in International Politics. International Organization 53 (2):397-408.

. 2002. Legitimacy, Power, and the Symbolic Life of the Security Council. Global Governance $8(1): 35-51$.

2005. The Great Powers and the UN Security Council: The Futile Search for Collective Security at San Francisco 1945 and Iraq 2003. In Approaches, Levels, and Methods of Analysis in International Politics: Crossing Boundaries, edited by Harvey Starr. New York: Palgrave Macmillan.

Ikenberry, G. John, and Charles A. Kupchan. 1990. Socialization and Hegemonic Power. International Organization 44 (3):283-315.

Johnston, Alastair Iain. 2001. Treating International Institutions as Social Environments. International Studies Quarterly 45 (4):487-515. 
Johnstone, Ian. 2003. Security Council Deliberations: The Power of the Better Argument. European Journal of International Law 14 (3):437-80.

Keohane, Robert O., and Lisa L. Martin. 1995. The Promise of Institutionalist Theory. International Security 20 (1):39-51.

Kirgis, Frederic. 2001. Terrorist Attacks on the World Trade Center and the Pentagon. ASIL Insights, No. 77. Washington, D.C.: American Society of International Law. Available at $\langle\mathrm{http}: / / w w w . a s i l . o r g /$ insights/insigh77.htm $\rangle$. Accessed 10 March 2004.

Levy, Jack S. 1994. Learning and Foreign Policy: Sweeping a Conceptual Minefield. International Organization 48 (2):279-312.

Lynch, Marc. 2002. Why Engage? China and the Logic of Containment. European Journal of International Relations 8 (2):187-230.

Martin, Lisa L. 1992. Coercive Cooperation: Explaining Multilateral Economic Sanctions. Princeton, N.J.: Princeton University Press.

Mattern, Janice Bially. 2004. Ordering International Politics: Identity, Crisis, and Representational Force. New York: Routledge.

Mearsheimer, John. 1994/95. The False Promise of International Institutions. International Security 19 (3):5-49.

Mercer, Jonathan. 1996. Reputation and International Politics. Ithaca, N.Y.: Cornell University Press.

Murphy, Sean D. 1999. Contemporary Practice of the United States Relating to International Law. American Journal of International Law 93 (1):161-94.

Niblock, Tim. 2001. 'Pariah States' and Sanctions in the Middle East: Iraq, Libya, Sudan. Boulder, Colo.: Lynne Rienner.

O’Neill, Barry. 1999. Honor, Symbols, and War. Ann Arbor: University of Michigan Press.

Reisman, W. Michael. 1993. The Constitutional Crisis in the United Nations. American Journal of International Law 87 (1):83-100.

Reser, Heather. 1998. Airline Terrorism: The Effect of Tightened Security on the Right to Travel. Journal of Air Law and Commerce 63 (4):819-58.

Risse, Thomas. 2000. "Let's Argue!": Communicative Action in World Politics. International Organization 54 (1):1-40.

Rose, Gideon. 1998. Libya. In Economic Sanctions and American Diplomacy, edited by Richard N. Haass, 129-56. New York: Council on Foreign Relations.

Schimmelfennig, Frank. 2003. The EU, NATO and the Integration of Europe: Rules and Rhetoric. Cambridge: Cambridge University Press.

Scott, James C. 1990. Domination and the Arts of Resistance: Hidden Transcripts. New Haven, Conn.: Yale University Press.

Vandewalle, Dirk. 1998. Libya Since Independence: Oil and Statebuilding. Ithaca, N.Y.: Cornell University Press.

Viorst, Milton. 1999. The Colonel in his Labyrinth. Foreign Affairs 78 (2):60-75.

Weldes, Jutta. 1999. Constructing National Interests: The United States and the Cuban Missile Crisis. Minneapolis: University of Minnesota Press. 